\title{
Ritual Penyembuhan dalam Shamanic Psychotherapy (Telaah Terapi Budaya di Nusantara)
}

\author{
Nuzulul Khair ${ }^{1}$ \\ Program Magister Psikologi \\ Fakultas Psikologi Universitas Gadjah Mada
}

\section{Pengantar}

Berbicara masalah pengobatan, baik itu pengobatan fisik maupun psikis, seringkali dibedakan antara pengobatan tradisional dan pengobatan modern. Modern dalam konteks ini berarti biomedis, sedangkan kata tradisional mengesankan bahwa pengobatan yang dipraktikkan sejak zaman dahulu (sebelum pengobatan biomedis di nusantara) yang dipertahankan sampai saat ini dalam bentuk yang relatif utuh. Maka, tidak mengherankan kalau pengobatan tradisional sering diasosiasikan dengan tempat dan manusia yang masih dianggap tradisional, yaitu identik dengan kampung, dengan budaya lokal etnis tertentu dan orang-orang sederhana yang kurang berpendidikan.

Pada beberapa komunitas tradisional, di mana tidak ada juru penyembuh yang modern seperti dokter maupun terapis, masih terdapat usaha-usaha untuk mengobati masalah kesehatan fisik dan psikis yang dilakukan secara adat. Mulai dari sakit ringan, sakit berat atau sakit akut (parah) hingga yang terkena halusinasi atau histeria yang dianggap disebabkan oleh makhluk gaib. Sistem penanganan semacam ini banyak ditemukan di berbagai budaya di belahan dunia, termasuk di Indonesia. Metode semacam ini lahir dari konsep yang berbeda mengenai sakit, cara

\footnotetext{
${ }^{1}$ Korespondensi mengenai isi artikel ini dapat
} dilakukan melalui: nuzul_calm@yahoo.co.id penyembuhannya pun tergantung pada pemahaman definitif-kultural berkenaan dengan sakit yang tengah didera.

Telah banyak fakta empiris terkait budaya asli dan tradisional dengan menggunakan pendekatan spiritual dan roh efektif untuk tujuan praktis penyembuhan. Penyembuhan tradisional selalu dipahami bahwa ada kekuatan alam yang berkolaborasi dengan manusia, dalam konteks ini dikenal dengan dukun, untuk tujuan penyembuhan. Menurut pandangan ini terdapat kekuatan alam semesta berupa roh-roh yang tak terlihat yang terselubung dari kapasitas reseptif dan memberi pengaruh terhadap situasi sehat dan sakit manusia secara berkelanjutan. Kebijaksanaan orang yang menyembuhkan dan kekuatan untuk berkomunikasi dengan dunia lain dibutuhkan sebagai bentuk tindakan kasih sayang (Prechtel, 2001).

Peranan dukun sendiri dianggap sebagai salah satu fenomena sosial budaya yang diyakini kekuatan magisnya, diantaranya seperti menjelang ujian nasional banyak orang datang dan pergi ke dukun untuk meminta doa restu, kelancaran jodoh, kelancaran dalam mendapatkan pekerjaan, penyembuhan dalam penyakit, dan kesuksesan dalam berdagang. Selain itu, dukun juga bisa berarti spesialis magis umum dalam masyarakat tradisional, berguna untuk semua orang sakit, baik fisik maupun psikologis, meramal kejadian masa depan, penemu barang-barang 
hilang, pemberi jaminan tentang peruntungan yang baik, serta biasanya tidak segan-segan mempraktikkan sedikit sihir, jikalau itu yang diminta seseorang (Geertz, 1989).

Proses seseorang untuk menjadi dukun tidak perlu mengikuti sekolah formal. Pada awalnya mulai dengan bekerja sebagai pembantu seorang dukun, yang biasanya adalah orang tua mereka sendiri. Orang Jawa misalnya, sangat yakin bahwa kemampuan serta keterampilan yang dimiliki oleh seorang dukun hanya didapatkan melalui disiplin yang ketat dan bertapa. Karena itu, orang yang menjadi dukun sering menjalankan puasa, semedi, tirakat maupun melakukan latihan-latihan kebatinan yang lain.

Geertz (1989) mengungkapkan bahwa para dukun ilmu gaib Jawa menggunakan teknik-teknik ilmu gaib, ucapan mantramantra dan memberikan jamu tadisional, tetapi yang terpenting adalah kondisi dari para pelakunya sendiri. Baik pria maupun wanita dapat menjadi seorang dukun. Seseorang yang menjadi dukun pada umumnya adalah orang dewasa yang sudah setengah tua. Ada kalanya, jika kita melihat dukun yang masih kanak-kanak, yang menurut cerita memiliki kemampuan untuk mengobati dan meramal, dan ada kanak-kanak yang menjadi seorang dukun prewangan, yang dapat mengundang roh halus ke dalam tubuhnya.

Menyambungkan energi dengan dunia lain memerlukan pemeliharaan energi yang mana saluran itu melampaui batasbatas diri dan ilusi, antara energi dan materi, antara nyata dan imaginal. Sebagai keadaan kesadaran yang melampaui persepsi keterbatasan dunia fisik perlu adanya juru penyembuh atau yang dikenal dukun dan ritual khusus yang dapat memfasilitasi aliran energi penyembuhan. Dalam metode penyembuhan tradisional salah satu cara untuk menjaring kekuatan salah satunya dengan menciptakan bendabenda yang disucikan, tarian dan terkadang mantra khusus yang mencerminkan penghormatan dan mewujudkan munculnya spirit kesembuhan.

Pentingnya keberadaan dukun dan proses ritual khusus di atas bukanlah hal yang dilebih-lebihkan, seperti yang dijelaskan Irwin (1994) ritual merupakan budaya teknologi yang visioner karena sebagian besar teknik penyembuhannya masih relevan sampai sekarang. Meski demikian, dalam kebudayaan Barat kontemporer sebagian besar tidak memiliki pengetahuan dan kemampuan untuk terlibat dengan makhluk alam gaib sehingga mereka menganggap metode semacam itu tidak bisa bertransformasi menjadi metode penyembuhan. Oleh sebab itu, interaksi kemudian menjadi sulit tanpa memahami kerangka konseptual yang jelas.

Kerangka konseptual yang dimaksud adalah mengenai konsepsi sakit. Sakit mempunyai konsep yang beraneka ragam. Namun, pada substansinya sakit berarti kondisi fisik maupun rohani seseorang sedang mengalami ketidakseimbangan. Bisa karena kerusakan pada organ tubuh maupun faktor keturunan, atau oleh wabah penyakit, perubahan cuaca, tekanan psikologis dan lainnya. Bahkan terdapat pula pandangan lantaran kerasukan makhluk halus. Bagaimana pengertian sakit dirumuskan akan memengaruhi solusi untuk mengatasi penyakit tersebut. Para juru sembuh pun menggunakan berbagai metode tergantung apa atau bagaimana penyakitnya.

\section{Ritual Penyembuhan}

Sebuah ritual penyembuhan adalah pengalaman transpersonal di mana peserta atau pasien terlibat dengan kekuatan kosmos yang cerdas untuk mengemba- 
likan atau mempertahankan kesehatan untuk individu dan masyarakat. Ritual penyembuhan dipraktikkan dalam kosmos yang hidup, didasarkan penghormatan pada makhluk lain di berbagai dunia, dengan asumsi bahwa kekuatan ini jika benar-benar diundang dan dihormati akan berpartisipasi dalam proses penyembuhan (Driver, 1997).

Terdapat banyak penelitian yang mempertimbangkan pentingnya ritual dalam proses penyembuhan penyakit, yang meliputi meminta roh mengilhami benda sakral dan menjembatani proses penyembuhan bekerja pada individu maupun kelompok. Some (1998) mengemukakan hasil riset yang menghasilkan fakta bahwa ritual itu bersifat pragmatis, tujuan sebenarnya adalah untuk memengaruhi dunia dengan mengubah atau mengkonfirmasi pola yang mendasari hubungan. Seperti kebanyakan modalitas penyembuhan pada individu, ritual bekerja pada tingkat energi. Dengan mengatur ulang konfigurasi energi dan informasi menciptakan dan mempertahankan realitas hubungan aspek-aspek diri, anggota sosial, ekologi masyarakat dan dengan roh.

Sedangkan hubungan antara ritual penyembuhan dengan kesehatan merupakan hal yang begitu erat kaitannya kehidupan manusia secara keseluruhan. Penyembuhan itu sendiri mempromosikan kesehatan dan keutuhan melalui pemeliharaan halhal yang fundamental dan sakral. Semua kehidupan dan kesehatan merupakan fungsi dari hubungan yang tepat antara individu sebagai bagian dari sistem dan kesatuan utuh yang muncul dari hubungan beberapa bagian (Metzger, 2002). Berdasarkan penjelasan ini ritual penyembuhan bukanlah sebuah sistem yang statis sesuai dengan akar kehidupan itu sendiri yang bersifat dinamis.
Proses penyembuhan dari situasi sakit dengan demikian merupakan proses yang sedang berlangsung untuk mempertahankan keseimbangan antara bagian-bagian dari sistem hidup secara keseluruhan. Dalam serangkaian sistem hidup ada yang namanya penciptaan, kehidupan, kehancuran dan kematian. Oleh karena itu, menurut Metzger (2002), sistem penyembuhan bukan hanya menyangkut untuk menghilangkan gejala patologis atau untuk membuat masalah pergi-melainkan untuk mendukung hubungan yang tepat dan mengurangi penderitaan baik bagi individu atau bagi masyarakat.

Proses ritual penyembuhan tergantung pada konstruksi kesadaran pada manusia. Sebagai kerangka teoretis terdapat tiga evolusi kesadaran manusia (Kremer, 1995). Terdapat tiga fase utama evolusi kesadaran manusia yang mencerminkan mode yang berbeda terkait partisipasi terhadap kenyataan: (a) partisipasi asli atau kesadaran adat, (b) partisipasi sadar atau kesadaran modern, (c) partisipasi akhir atau masa depan. Masingmasing mode kesadaran memanfaatkan konstruksi yang berbeda dari interaksi objek-subjek atau hubungan diri dengan alam semesta.

Menurut Kremer (1994) dalam partisipasi asli atau pikiran adat yang muncul pada era pemburu-pengumpul, kesadaran manusia tertanam di alam dengan batasbatas yang sangat permeable antara diri dan fenomena. Sintesis kesadaran ini memungkinkan pengalaman koneksi sistemik dengan alam dan persepsi yang dibedakan dari keseluruhan. Dalam partisipasi asli, berpikir dalam gambar lebih mendominasi daripada pemikiran konseptual dan pengalaman transkultur merupakan fenomena yang biasa terjadi. Mungkin yang paling signifikan, partisipasi asli memerlukan kesadaran spiritual dan peran mereka 
bermain dalam kehidupan yang lebih besar.

Tahap kedua, partisipasi sadar atau kesadaran modern, muncul di abad ke-17 dan merupakan modus utama kesadaran dalam budaya barat modern. Dalam transisi ke mode ini, pusat persepsi dan berpikir bergeser dari keterlibatan intersubjektif dengan fenomena untuk fokus pada diri, dan pikiran terputus hubungannya dengan alam. Akibatnya, manusia dalam pengalaman kesadaran modern disosiasi dari kedua alam dan ketidaksadaran kolektif. Akses kolektif ke pola dasar dunia atau roh masih jarang, meskipun orang masih mengakses dimensi tersebut melalui mimpi dan peristiwa transpersonal lainnya. Kognisi intelektual diprioritaskan, sementara emosional, somatik, dan cara-cara spiritual untuk tidak begitu dievaluasi.

Pada fase kesadaran ketiga, merupakan fase yang menjadi inti kajian dalam makalah ini yakni menyangkut konsep shamanic psychotherapy. Pola kesadaran partisipasi masa depan (untuk peserta atau pasien yang memiliki kesadaran modern), menekankan pentingnya kesadaran pada kekuatan spiritual, penghormatan, dan pentingnya berkomunikasi kembali dengan kekuatan alam. Partisipasi masa depan merupakan pekerjaan dari perdukunan kontemporer, melibatkan pula praktik transkultural, munculnya mitologi baru dalam kerangka kerja mimpi individu dan kembalinya kesadaran pada pentingnya upacara dan ritual.

Manusia bertindak berdasarkan kesadaran modern saat ini begitu mendominasi, meskipun di banyak bidang banyak ditemukan orang-orang untuk menemukan partisipasi lebih dengan dunia yang lain. Meski demikian, pada saat ini di tengah kejenuhan masyarakat modern dengan berbagai masalah yang terus muncul dalam kehidupan sehari-hari mereka, yang mana tidak mudah diselesaikan, masyarakat modern mulai mengalami proses evolusi di mana mereka meningkat kesadarannya pada pentingnya kembali pada hal-hal yang berhubungan dengan spiritualitas.

Saat ini, telah banyak berkembang metode penyembuhan yang menekankan pada sisi akulturasi, membawa alam pikiran modern dengan memulihkan kesadaran adat mereka. Salah satu bentuk praktik dalam metode penyembuhan ini yaitu memfokuskan pada ethnoautobiography, yaitu pendekatan leluhur, yang memerlukan pemulihan terhadap kesadaran adat dengan kembali ke akar silsilah seseorang, mitos, sejarah kolektif leluhur, serta menghadirkan serangkaian upacara (Kremer, 1994). Model penyembuhan ini mengeksplorasi bagaimana berkomunikasi dengan kekuatan spiritual melalui berbagai cara termasuk ritual, perhatian terhadap pertanda, adanya mantra, dan nubuat sebagai medium sinkronitas dengan alam semesta.

\section{Perdukunan dan Psikoterapi}

Keberadaan seorang dukun dalam praktik pengobatan tradisional begitu penting. Bukti sejarah menunjukkan keberadaan praktik perdukunan sudah ada sejak 40.000 tahun yang lalu, dan praktiknya terus berkembang hingga saat ini. Prinsip yang dilakukan adalah sama dengan metode penyembuhan modern, yaitu membimbing klien untuk memahami masalah yang sedang dihadapi dan membantunya dalam proses penyembuhan. Kategori penyakit yang disembuhkan juga beragam, mulai dari penyembuhan depresi, penyembuhan keluhan fisik dengan komponen spiritual dan psikologis, pemberdayaan, melepaskan rasa malu 
bahkan menghapus kutukan (Kremer, 1995).

Perdukunan bisa dianalisis dari perspektif bidang kajian psikologi, yaitu pendekatan psikoterapi. Kedekatan kedua konsep ini bisa ditelaah dari pemikiran Freud dan Jung yang diterima sebagai pendiri psikologi. Dimana Freud banyak berkutat dalam analisis pikiran dan perilaku, Jung tampaknya lebih terbuka terhadap pasang surut dan aliran pengalaman energik dari dunia dalam dan luar dari jiwa. Freud bekerja sebagian besar dari pikiran, cara yang logis, dan Jung adalah lebih terbuka untuk koneksi ke pengalaman, pada energi, mirip dengan jalan pengalaman dari Shaman atau dukun.

Jung berangkat melalui pengalaman inisiasi perdukunan di mana dia merasa dia akan gila, dia mundur dari kehidupan pada saat ini dalam beberapa waktu dan pergi jauh ke dunia lain. Ketika Jung berbicara tentang pengalamannya dia mengatakan dia percaya bahwa seseorang memiliki kemampuan untuk menghubungkan dan berinteraksi dengan energi yang jauh lebih besar dari yang dibayangkan. Hal ini, dengan nama lain, adalah perdukunan. Prinsip energi yang memiliki pola perilaku sendiri membentuk dasar untuk pola dasar Psikologi Jung.

Jung secara khusus menulis tentang inisiasi perdukunan di dalam buku Memories, Dreams, Reflections (1989). Di dalam buku ini Jung menjelaskan bahwa dia mungkin tidak tahu pada saat itu terkait apa peristiwa yang dialaminya, tapi ia kemudian dikenal oleh murid-muridnya sebagai "Dukun Psikoterapi". Dalam tahun-tahun berikutnya, Jung bepergian secara luas di seluruh dunia untuk mempelajari perdukunan. Jung menyadari bahwa terlepas dari perbedaan jelas, baik perdukunan dan psikologi analitis, Jung yakin keduanya sama-sama berfokus pada penyembuhan dan pertumbuhan jiwa.

Pekerjaan Jung telah mengakar ke daerah lain dalam kajian Psikologi. Otto Rank, seorang rekan Jung, kemudian sangat tertarik pada mitologi, seni dan cerita dalam psikologi. Prinsip psikoterapinya adalah bertumpu pada pengalaman "disini dan sekarang". Kliennya dijadikan rekan yang terlibat pada kesadaran akan energi yang berada di ruangan saat dia bekerja secara langsung dengan mereka. Dia juga menyadari bahwa manusia harus terhubung ke sesuatu yang lebih besar daripada mereka.

Fritz Perls, pendiri Gestalt Psikoterapi sangat dipengaruhi oleh Otto Rank. Teknik Gestalt ciri khasnya adalah teknik dua kursi, prinsipnya bekerja sama dengan situasi di sini dan sekarang, juga bekerja dengan prinsip kekuatan energi di dalam ruangan. Sebuah kursi yang kosong dibawa ke ruangan dan klien membahas kursi kosong di tempat ayah mereka, ibu mereka, atau siapapun bahwa mereka berada dalam kesulitan hubungan dengan mereka. Klien kemudian duduk di kursi dan menjadi orang lain, kemudian menjawab kembali untuk mereka sendiri. Telah ditemukan fakta bahwa hal ini bukan sebuah roleplay biasa, entah bagaimana energi orang tersebut hadir dan berbicara melalui klien. Terapis dan klien menjadi saksi dan mereka dapat mempelajari faktafakta baru, mendapatkan pemahaman baru perilaku seseorang dan seringkali resolusi dapat dicapai tanpa menghadirkan orang lain secara fisik.

Pendekatan ini juga berlaku dalam Terapi Keluarga hasil rekonstruksi Virginia Satir. Kelompok orang asing diatur secara spasial di kamar "menjadi" bibi, paman, ayah, saudara dalam keluarga yang mana mereka belum pernah bertemu. Dimana orang dalam keluarga telah 
meninggal, ia masih dipanggil untuk mewakili mereka jika mereka merupakan bagian integral dari cerita yang perlu penyembuhan. Ketika interaksi terjadi antar anggota keluarga, pergeseran energi yang terjadi mengubah dinamika sebenarnya di dalam keluarga, dengan demikian bisa menyembuhkan perpecahan keluarga. Hebatnya, ditemukan bahwa kesenjangan cerita di mana informasi yang hilang karena kematian dalam keluarga diisi melalui pesan yang diberikan kepada orang-orang melalui energi peran mereka.

Rekonstruksi Terapi Keluarga dan Terapi Gestalt berdasarkan deskripsi di atas jelas berkaitan kuat dengan interaksi antara dunia perdukunan dan entitas energik. Seperti dapat dilihat dari contoh di atas, ada hubungan mendalam antara psikologi dan perdukunan, dan mereka memiliki banyak kesamaan. Keduanya bekerja dengan jiwa manusia. Keduanya memberikan kesembuhan bagi klien. Baik dukun maupun psikoterapis memberikan ruang bagi klien untuk pergi melalui proses penyembuhan jiwa. Dan keduanya, praktisi perdukunan dan psikoterapis harus melalui proses penyembuhan diri agar mampu memfasilitasi proses penyembuhan klien mereka.

Perbedaan utama antara keduanya adalah perdukunan yang merupakan panggilan melalui proses inisiasi dapat tidak terjadi pada orang-orang yang tidak mencari atau melalui proses itu. Sedangkan psikoterapis atau psikolog memilih jalur studi, bahkan jika perlu berasal dari pikiran bawah sadar, jadi tidak selalu terlibat dalam proses inisiasi diri. Meski begitu, di dalam pekerjaan pribadi mereka banyak yang mempraktikkan proses perdukunan. Beberapa melakukan, dan semakin banyak dari mereka yang beralih ke perdukunan untuk mendukung transformasi penyembuhan.

\section{A. Ritual Penyembuhan di Nusantara}

Ritual Penyembuhan "Pedole-Dole": Praktik Penyembuhan Masyarakat Wolid

Di daerah ini pengobatan leluhur ditujukan pada anak-anak yang sakit ringan. Ritual penyembuhannya juga berfungsi sebagai media silaturrahmi keluarga dan hal ini memberikan efek positif yaitu memberikan ketenangan psikologis bagi keluarga yang anaknya sedang sakit. Hal ini merupakan suatu kebiasaan masyarakat nelayan yang mendiami pesisir pantai pulau Buton. Acara ini biasanya untuk anak yang sawan, luka-luka di bagian kepala, gatal-gatal atau sering sakit-sakitan karena dipercaya kurang cocoknya nama yang diberikan. Adapun yang berperan dalam memandu acara ini adalah seorang dukun perempuan yang disebut oleh masyarakat etnis Wolio/Buton di ujung selatan propinsi Sulawesi Tenggara sebagai 'bisa'.

Ketika tiba saat acara "Pedole-pedole", ibu-ibu datang berkumpul di tempat acara dengan tidak lupa membawa serta anakanaknya. Pelaksanaannya biasanya menjelang sore hari. Mereka percaya bahwa jika anaknya sakit-sakitan atau terkena penyakit kulit seperti bisul-bisul atau gatal-gatal berarti anaknya belum pernah didole-dole. Di tengah beranda rumah yang luas nampak semua bahan yang sudah matang diletakkan berjejer di tempat-tempatnya. Para ibu duduk mengelilingi, sambil memangku anakanaknya. Anak yang ikut sudah terlebih dahulu mandi yang bersih dari rumahnya masing-masing.

Setelah itu biasanya 'bisa' mulai membaca mantra-mantra di tengah kepulan asap kemenyan yang memenuhi ruangan. Kemudian satu persatu periuk ditutup 
rapat dengan daun pisang dipotong dengan menggunakan parang kayu. Kemudian pucuk daun pisang muda yang disediakan bagi setiap anak dibuka dan dilumuri dengan minyak kelapa sambil diberi mantra-mantra.

Satu-persatu anak dimantrai dan dipangku oleh bisa. Lalu digulingkan di atas lumuran minyak yang terlebih dahulu dilumuri kunyit sebanyak sekian kali. Seterusnya anak itu diangkat (secara tengkurap) sebanyak tiga kali di atas hidangan yang sejajar. Dan pada kali yang teakhir anak disuap mulutnya sedikitsedikit dari setiap hidangan tersebut, mulai dari nasi, kuning telur, ikan panggang dan sebagainya. Begitulah secara berturutturut balita yang ikut acara "dole-dole" diperlakukan dan anak yang sakit-sakitan biasanya berangsur-angsur sembuh.

\section{Ritual Penyembuhan 'Bodaya': Mengobati Sambil Menari dan Menyanyi}

Salah satu metode penyembuhan yang memanfaatkan kekuatan spiritual dan gaib adalah pada masyarakat Sasak, Bayan, wilayah sebelah utara pulau Lombok, Nusa Tenggara Barat. Sistem pengetahuan lokal memang sering memiliki tingkat 'rasa' yang berbeda terhadap kesakitan yang sama. Pada umumnya bagi orang Bayan, misalnya ada orang yang pergi bekerja ke sawah atau ke ladang sementara orang tersebut terserang demam atau flu mereka mengatakan hal itu tidak perlu mendapatkan bantuan 'tenaga medis' untuk mengatasi. Seseorang tersebut akan bisa mengatasi masalah sakit tersebut dengan caranya sendiri.

Berbeda dengan apabila ada seseorang yang sering gelisah, tidak nyaman, diikuti oleh demam yang naik-turun dari hari ke hari, teriak-teriak, maka orang tersebut bisa dikategorikan sebagai orang yang memiliki penyakit serius. Menurut kepercayaan, bukan petugas medis yang bisa menyelesaikan masalah ini. Jadi, lazimnya hal itu dibicarakan di antara keluarga, berdiskusi dengan dukun setempat berkaitan dengan diagnosis, penanganan dan bentuk apa yang cocok untuk memulihkan keadaaan.

Praktik penyembuhan penyakit di atas biasanya disebut dengan sekehe bodaya. Suatu kelompok kesenian yang menurut adat ditugasi mempraktikkan penyembuhan yang dipimpin oleh seorang juru penyembuh secara khusus diundang pada tempat dan waktu yang ditentukan sesuai dengan segala kebutuhannya. Beberapa tetua keluarga, kerabat yang mampu memainkan bodaya juga diundang agar aktif menjadi partisipan.

Pada malam hari, ketika segala sesuatu sudah siap untuk penyelenggaraan prosesi, seseorang pihak keluarga pasien membuka acara setelah itu ada prosesi doa yang dipimpin oleh juru penyembuh kepada Tuhan. Acara pembukaan disebut mesilak, disampaikan menurut susunan bahasa baku menurut adat namun dimengerti oleh khalayak karena diungkapkan dalam bahasa Bayan. Permohonan penyembuhan bukan hanya menyangkut si pasien, akan tetapi juga meluas bagi kesejahteraan seluruh keluarga.

Bodaya itu sendiri terdiri dari tiga unsur: pertama, seni pertujunjukan; kedua; komunikasi spiritual dengan perantara (media) pemain bodaya yang mengalami trance ringan, dan ketiga; prosesi penyembuhan. Prosesi penyembuhan sebetulnya sudah dimulai segera setelah tahap menyilak. Si pasien kemudian dimantrai, di-sembek-ditempeli sedikit mamakan, yakni sirih-pinang yang telah dikunyah, ke dahi seseorang setelah dibacai doadan didupai. Setelah itu si pasien ikut menyaksikan pertunjukkan bodaya hingga larut. Sang penari menjadi mediator alam 
gaib, kemudian akan berdialog, mengomentari dan memberikan saran-saran mengenai proses penyembuhan.

\section{Peran Remembered Wellness dalam Shamanic Psychotherapy}

Keberadaan seorang dukun, biasanya dikenal sebagai sosok yang sakti, di Jawa terkadang disebut 'orang pintar'. Biasanya 'orang pintar' melalui proses yang disebut ngelmu. Ngelmu diperoleh dengan cara belajar dari dukun lain yang dianggapnya sebagai seorang guru. Geertz (1989) mengungkapkan bahwa ngelmu biasanya dianggap sebagai suatu jenis pengetahuan abstrak atau suatu keahlian supranatural yang kadang-kadang diyakini sebagai kekuatan magis pengganti, yang penggalihannya dapat diterima secara langsung tanpa melalui proses pengajaran.

Menurut Saputra (2007), ngelmu dapat dimaknai sebagai suatu pengetahuan praktis yang integral dengan dimensi mistis yang diperoleh melalui cara laku mistik. Artinya, ngelmu tidak sekadar untuk diketahui, akan tetapi juga harus dijalani atau dipraktikkan. Pada awalnya, mistik digunakan untuk menenangkan fluktuasi perasaan dalam kehidupan sehari-hari dan mencapai keadaan damai di hati. Selain itu, dalam mencapai keadaan mistik, orang harus ngesti dan nuwun.

Menurut Saputra (2007), ngesti merupakan suatu keadaan untuk menyatukan semua kekuatan individu dan mengarahkannya langsung kepada suatu tujuan tunggal yakni memusatkan kemampuan psikologis dan fisik dalam arah satu tujuan yang sempit. Artinya, penggabungan dari seluruh indra, emosi, dan seluruh proses fisik dalam tubuh. Nuwun berarti memohon atau meminta kepada Tuhan agar dianugerahkan pengetahuan suatu energi, sehingga orang dapat sampai kepada-Nya meskipun ada unsur-unsur perasaan dan sensasi duniawi yang menolaknya.

Oleh sebab itu, dinamika psikologis dari peluang kesembuhan (prognosis) pasien yang mengikuti ritual penyembuhan adalah banyak ditentukan oleh keyakinan pasien akan kesembuhan dan kepercayaan kepada juru penyembuh atau dukun. Hal ini di dalam dunia psikologi disebut dengan efek plasebo. Plasebo (Nevid, 2005) pada awalnya adalah sebuah pengobatan yang tidak berdampak atau penanganan palsu yang bertujuan untuk mengontrol efek dari pengharapan. Istilah plasebo diambil dari bahasa latin yang berarti "I shall please" (saya akan senang) yang mengacu pada fakta bahwa keyakinan akan efektivitas dari suatu penanganan akan dapat membangkitkan harapan yang membantu mereka menggerakkan diri mereka sendiri untuk menyelesaikan permasalahan - tanpa melihat apakah substansi yang mereka terima adalah aktif secara kimiawi atau tidak aktif.

Setelah itu, efek penyembuhan yang menekankan pada aspek keyakinan untuk sembuh disebut dengan efek plasebo. Namun, saat ini sudah dikenal istilah remembered wellness sebagai pengembangan dari efek plasebo. Pandangan ini dikemukan oleh Dr. Herbert Benson dari Harvard Medical school. Remembered wellnesss adalah kemampuan seseorang untuk mengingat kondisi semasa sehat. Benson menyimpulkan tiga cara untuk menjalani remembered wellness yaitu keyakinan dan harapan pasien, kehayakinan dan harapan dokter dan keyakinan dan harapan yang tumbuh dari hubungan pasien dan dokter.

Jadi berdasarkan konsep remembered wellness di atas, bahwa faktor yang ditekankan di dalam ritual penyembuhan masyarakat tradisional adalah munculnya keyakinan untuk sembuh yang ditopang 
oleh hubungan yang holisitik dengan terapis dalam hal ini dukun dengan praktik pengobatan yang familier dengan pasien. Misalnya, pada kasus orang yang terkena penyakit maag, bukan obat yang diberikan melainkan dupa harum agar orang yang sedang sakit lebih merasa tenang. Selain itu, adalah peran mantra ataupun doa-doa yang dipanjatkan menambahkan keyakinan pada si pasien sehingga memberikan peluang kesembuhan lebih cepat.

Tanpa intervensi psikologis yang sistematis, seseorang yang datang dengan beragam masalah kepada dukun atau 'orang pintar' dapat juga menyembuhkan dirinya sendiri karena peran remembered wellness tersebut. Jika percaya bahwa dengan perantara dukun atau doa-doa pada Tuhan bisa menyembuhkan, maka tubuh bereaksi positif terhadap obatobatan ataupun ritual yang diberikan, sehingga sembuh. Meskipun ritual itu sebenarnya hanya sebatas medium. Diketahui bahwa remembered wellness memberikan efek dalam penyembuhan diabetes, bisul perut, artritis, penyakit parkinson, sakit terkena radiasi, dan lainnya. Bahkan, secara mengejutkan, pada laki-laki maupun perempuan yang menginginkan pertumbuhan rambut, lantas hanya diberi plasebo, 11\% diantaranya benar-benar mengalami pertumbuhan rambut.

Biasanya orang yang datang ke pada penyembuh baik itu dukun (saat ini banyak berkembang sebutan paranormal), karena telah putus asa dan berhenti berharap bisa disembuhkan oleh pengobatan medik. Jadi, banyak yang merasa bahwa datang ke praktisi paranormal adalah harapan terakhirnya. Dalam kondisi tersebut, mereka mudah berada dalam keadaan super-tersugesti, dan memiliki harapan sangt tinggi. Oleh sebab itu mekanisme penyembuhan dirinya juga meningkat tajam sehingga bisa sembuh. Jadi, sembuhnya sakit bukan karena kemampuan dukun, tapi oleh ketidaksadarannya sendiri.

\section{Penutup}

Beragam penelitian terkait praktek penyembuhan yang dilakukan oleh para dukun pada suku-suku Indian Amerika Utara, oleh antropolog Claude LeviStrauss, menunjukkan hal serupa. Penyembuhan lebih banyak tergantung karena kepercayaan masyarakat dan si sakit terhadap dukun, dari pada karena kemampuan dukun. Bahkan, kemampuan dukun justru dinilai paling tidak penting.

Besarnya tingkat kepercayaan masyarakat di Indonesia terhadap fenomena dukun dan kekuatan paranormal, boleh jadi membuat metode penyembuhan shamanic psychoterapy atau beragam penyembuhan alternatif menjadi sangat efektif. Itulah sebabnya, praktik-praktik pengobatan alternatif tumbuh subur dimana-mana. Berdasarkan pandanganpandangan di atas maka dapat dikatakan bahwa peran rememberd wellness merupakan hal cukup penting dalam praktik penyembuhan, baik itu di lingkungan penyembuhan tradisional maupun modern.

\section{Daftar Pustaka}

Driver, T. F. (1998). Liberating rites: Understanding the transformative power of ritual. Boulder, CO: Westview Press.

Irwin, L. (1994). The dream seekers: Native American visionary traditions of the Great Plains. Norman, OK: University of Oklahoma Press. 
Geertz, C. (1989), Abangan, Santri, Priyayi dalam Masyarakat Jawa. Jakarta: Pustaka Jaya.

Kremer, J. W. (1995). Perspectives on Indigenous healing. Noetic Sciences Review, Spring, 33, 13-18.

Metzger, D. (2002). Entering the ghost river: Meditations on the theory and practice of healing. Topanga, CA: Hand to Hand.
Prechtel, M. (1998). Secrets of the talking jaguar: A Mayan shaman's journey to the heart of the Indigenous soul. New York, NY: Tarcher.

Somé, M. P. (1998). The healing wisdom of Africa: Finding life purpose through nature, ritual, and community. New York, NY: Tarcher/Putnam.

Nevid, J. (2005). Psikologi Abnormal. Jakarta:Erlangga. 